\title{
Protective Effect of Vitamins $C$ and E against Gasoline Vapors Induced Haematological and Biochemical Changes in Male Rats
}

\author{
A. Sedky ${ }^{1}$, H. Elsawy ${ }^{2,3 *}$ \\ ${ }^{1}$ Department of Zoology, Faculty of Science, Alexandria University, Egypt \\ ${ }^{2}$ Chemistry Department, Faculty of Science, Tanta University, Tanta, Egypt \\ ${ }^{3}$ College of Science, King Faisal University, Al-Ahsaa, P.B. Box 380, Hufof 31982, Saudi \\ Arabia
}

Received 23 May 2015, accepted in final revised form 12 August 2015

\begin{abstract}
The present work was designed to investigate the changes in some hematological, biochemical parameters and lipid profile as well as possible protective role of vitamins $\mathrm{C}$ and $\mathrm{E}$ against gasoline vapors induced toxicity in male rats. The present results showed that gasoline 80 vapors significantly decreased $(p \leq 0.05)$ the concentration of total serum protein (TSP) and albumin concentrations and increased $(\mathrm{p} \leq 0.05)$ in serum activities of serum aminotransferases (ALT and AST) and alkaline phosphatase (ALP) compared to the control group. Also, exposure to gasoline 80 vapors induced significant decrease $(\mathrm{p} \leq 0.05)$ in hemoglobin concentration, red blood cell count (RBCs), packed cell volume (PCV) and high density lipoprotein cholesterol (HDL-C) compared to control group. On the other hand, exposure to gasoline 80 vapors resulted in significant increase $(\mathrm{p} \leq 0.05)$ in the levels of total cholesterol (TC), triglycerides (TGs), LDLcholesterol (LDL-C) and very low density lipoprotein cholesterol (VLDL-C) relative to untreated experimental animals. However, concomitant treatment with gasoline vapors and administration of vitamins $\mathrm{C}$ and $\mathrm{E}$ exhibited a protective role on the observed toxic effect of gasoline vapors in male rats. The results of the present study indicated that toxic effects of gasoline vapors could be reduced by dietary supplementation of vitamins $\mathrm{C}$ and $\mathrm{E}$.
\end{abstract}

Keywords: Gasoline vapors; Vitamin C; Vitamin E; Lipid profile; Haematology; Liver enzymes.

(C) 2015 JSR Publications. ISSN: 2070-0237 (Print); 2070-0245 (Online). All rights reserved.

doi: http://dx.doi.org/10.3329/jsr.v7i3.23462 J. Sci. Res. 7 (3), 139-149 (2015)

\section{Introduction}

Gasoline, a fractionated product of crude oil, is a mixture of over 500 hydrocarbons that may have between 3-12 carbon atoms. It is used as fuel for automobiles and some

* Corresponding author: hmostafa@kfu.edu.sa, hany.mostafa@science.tanta.edu.eg 
electricity-generating machines [1,2]. Human population is directly or indirectly exposed to this pollutant in the course of their day-to-day activities [3]. Gasoline enters the body orally (accidental), transdermally, and by inhalation but inhalation route is more important because more persons may be affected [4]. Source of exposure to gasoline involve refueling stations, motor mechanical workshops, and trafficcongested area and occupationally [3]. It is well known that exposure to gasoline vapors causes serious health hazards to humanity [5].

It has been reported that gasoline vapors induced changes in serum lipid profile and haematotoxicity [6,7]. Also, several studies have reported that petroleum and its products have the ability to increase the level of liver marker enzymes [8-10]. Vitamin A, vitamin C, vitamin $\mathrm{E}$ and selenium are among nutrients with antioxidant activity. Humans obtain vitamin $C$ from vegetable, fruit and other plant food because they are unable to synthesize it. Vitamin C can suppress activities of free radicals such as reactive oxygen species (ROS), the high levels of which are thought to initiate cancer through oxidative damage to DNA. Vitamin E is the major lipid-soluble antioxidant in serum and has the ability to inhibit the generation of singlet oxygen, free radicals, lipid radicals and lipid hydroperoxides [11].

Oxidative stress is one among the molecular mechanisms responsible for the toxicity associated with exposure to gasoline vapors, which disturbs the antioxidant defense system and produced alteration in lipid peroxidation $[6,12]$.

From the above mentioned data, it was thought that it is important to investigate the possible protective effect of vitamins $\mathrm{C}$ and $\mathrm{E}$ against haematological and biochemical changes induced by exposure to gasoline vapors in male rats.

\section{Experimental}

\subsection{Experimental animals}

This study was carried out on twenty male rats (wistar albino). The rats weighed 180$200 \mathrm{~g}$ and were of more or less the same age (3-3.5 month old). The experimental animals were obtained from the animal house of Faculty of Medicine, Alexandria University. They were allowed to acclimatize, one week before the commencement of the experiment, under normal laboratory conditions and were allowed to free access of a standard balanced laboratory diet (wheat, milk and carrot) and tap water. Animals were randomly divided into four groups of five animals each and were housed in steel cages.

\subsection{Treatment of rats with vitamins $E$ and $C$}

Vitamins $\mathrm{E}$ and $\mathrm{C}$ were solubilized in olive oil and distilled water, respectively. Prophylactic doses of vitamin E (150 mg/kg body weight) and vitamin C (200 mg/kg body weight) were used in the present study. Administration was done by oral 
gavaging using intragastric syringe. The used vitamin solutions were kept at room temperature and protected from direct contact with air and light to avoid degradation.

\subsection{Exposure to gasoline vapors}

The experimental animals were exposed to gasoline vapors for one hour daily for 6 weeks. Exposure was achieved by using the method as reported elsewhere [4]. $20 \mathrm{~g}$ of cotton wool was soaked with $5 \mathrm{~mL}$ of commercially procured gasoline 80 and then plastered on one end of the animal cages. The vapor was allowed to mix with the ambient air of the cages and the larger environment and about 1-2 $\mathrm{mL}$ of the gasoline was vaporized in the ambient air of each animal cage for one hour. The exposure modality stimulated a general occupational oil depot environment in which gasoline saturated the ambient air to which unprotected workers in the fuel station are exposed daily for hours. The piece of soaked cotton was daily changed.

Gasoline (red color) having octane number 80 was obtained from fuel station in one liter clean bottle.

\subsection{Experimental design}

The experimental rats were divided into four groups and each group consists of six rats. GI (Control) was allowed to respiration in fresh air with no exposure to gasoline vapors. GII (Negative control) was daily exposed to vapors of gasoline solution of octane number 80 only for $1 \mathrm{~h}$ for 6 weeks. GIII was daily exposed to vapors of gasoline solution of octane number 80 only for $1 \mathrm{~h}$ and concomitantly treated with vitamin (C) and vitamin E for 6 weeks. GIV was administered with vitamins $\mathrm{C}$ and $\mathrm{E}$ for 6 weeks.

\subsection{Preparation of blood}

At the end of the experiment, blood sample was collected from each animal from retro-orbital sinus of the eye (after a mild anesthesia by inhalation) using heparinized capillary tube into clean bottle containing ethylene diaminetetracetic acid (EDTA) as anticoagulant for haematological analysis.

\subsection{Determination of haematological parameters}

Red blood cell counts (RBCs) and packed cell volume (PCV) were determined according to the reported method [13]. Reagent kits for determination of haemoglobin concentration $(\mathrm{Hb})$ were purchased from Biodiagnostics (Egypt). 


\subsection{Preparation of serum}

Whole blood samples collected in clean dry centrifuge tubes, containing no anticoagulation factors were allowed to clot for a minimum of $30 \mathrm{~min}$ at $37^{\circ} \mathrm{C}$ before centrifuged to obtain serum (1500 rpm for $15 \mathrm{~min}$ ) and stored at $-20^{\circ} \mathrm{C}$ until the analysis.

\subsection{Determination of serum lipid profile parameters}

Levels of total cholesterol (TC), triglycerides (TGs), and high density lipoprotein cholesterol (HDL-C) were determined by standard kits (BIOMED Diagnostics, Germany) according to the instructions of the supplier. The levels of LDL-cholesterol (LDL-C) and very low density lipoprotein cholesterol (VLDL-C) were calculated using Friedewal's formula [14], the units were expressed as mg/dL.

\subsection{Evaluation of the liver function}

Activities of serum aminotransferases (ALT and AST) and alkaline phosphatase (ALP) were measured using BioMed Diagnostics kit, Germany, according to the instructions of the supplier. Serum total protein level was carried out according to the manual of BioMed Diagnostics kit, Germany. Serum albumin level was determined as outlined in SPECTRUM Diagnostics kit.

\subsection{Statistical analysis}

Results were presented as mean \pm standard error (SE). All variables were compared using one-way analysis of variance (ANOVA) followed by LSD multiple range test. Differences at $\mathrm{p}<0.05$ were considered significant.

\section{Results}

Table (1) shows that inhalation of gasoline 80 (G II) significantly ( $\mathrm{p} \leq 0.05$ ) lowers the values of Hb concentration, PCV and RBCs count relative to values obtained for the control group. Inhalation of gasoline 80 followed by concomitant treatment with vitamin $\mathrm{C}$ and vitamin E significantly $(\mathrm{p} \leq 0.05)$ increase the values of Hb content, PCV and the RBC count when compared with gasoline 80 inhaled group. Treatment with vitamins $\mathrm{C}$ and $\mathrm{E}$ did not affect significantly $(\mathrm{p} \leq 0.05)$ the hematological parameters when compared with control group.

Serum lipid profile of the experimental animals, exposed to gasoline 80 vapors and treated with vitamins $\mathrm{C}$ and $\mathrm{E}$ are shown in Table 2. It is obvious that inhalation of gasoline 80 vapors produced significant increase $(\mathrm{p} \leq 0.05)$ in the values of TC, TGs, LDL-C, and VLDL-C relative to the control group. Also, the results showed that 
HDL-C level significantly decreased $(\mathrm{p} \leq 0.05)$ relative to that obtained for control group.

Table 1. The effect of gasoline 80 vapors on Hb concentration, PCV and RBCs count in male rats.

\begin{tabular}{llll}
\hline & Hb $(\%)$ & PCV $(\%)$ & $\begin{array}{l}\text { RBCs count } \\
(\text { million cells/ } / \mu \mathrm{L})\end{array}$ \\
\hline Group I & $12.44^{\mathrm{a}} \pm 0.12$ & $45.0^{\mathrm{a}} \pm 1.45$ & $4.52^{\mathrm{a}} \pm 0.08$ \\
Group II & $10.0^{\mathrm{b}} \pm 0.20$ & $34.0^{\mathrm{b}} \pm 0.58$ & $3.81^{\mathrm{b}} \pm 0.11$ \\
Group III & $11.90^{\mathrm{c}} \pm 0.07$ & $39.20^{\mathrm{c}} \pm 1.02$ & $4.12^{\mathrm{c}} \pm 0.08$ \\
Group IV & $12.24^{\mathrm{a}} \pm 0.09$ & $44.40^{\mathrm{a}} \pm 0.93$ & $4.37^{\mathrm{a}} \pm 0.01$ \\
F (p) & $19.103^{*}\left(<0.001^{*}\right)$ & $10.136^{*}\left(<0.001^{*}\right)$ & $12.633^{*}\left(<0.001^{*}\right)$ \\
\hline
\end{tabular}

Normally distributed data was expressed in mean \pm SE and was compared using $F$ test (ANOVA) and was using Post Hoc Test (LSD) for comparison between groups. The different superscripts are significant $*$ : Statistically significant at $\mathrm{p} \leq 0.05$, Number of animals 5 male rats/group.

Table 2. Effect of vitamins $\mathrm{C}$ and $\mathrm{E}$ administration on serum lipid profile of male rats exposed to gasoline 80 vapors.

\begin{tabular}{llllll}
\hline & TC $(\mathrm{mg} / \mathrm{dL})$ & TGs $(\mathrm{mg} / \mathrm{dL})$ & $\begin{array}{l}\text { HDL-C } \\
(\mathrm{mg} / \mathrm{dL})\end{array}$ & $\begin{array}{l}\text { LDL-C } \\
(\mathrm{mg} / \mathrm{dL})\end{array}$ & $\begin{array}{l}\text { VLDL-C } \\
(\mathrm{mg} / \mathrm{dL})\end{array}$ \\
\hline Group I & $112.40^{\mathrm{a}} \pm 2.14$ & $125.40^{\mathrm{a}} \pm 1.08$ & $44.0^{\mathrm{a}} \pm 0.63$ & $68.16^{\mathrm{a}} \pm 0.57$ & $22.40^{\mathrm{a}} \pm 0.81$ \\
Group II & $204.75^{\mathrm{b}} \pm 1.49$ & $206.50^{\mathrm{b}} \pm 2.53$ & $32.75^{\mathrm{b}} \pm 0.85$ & $160.20^{\mathrm{b}} \pm 1.04$ & $32.0^{\mathrm{b}} \pm 0.41$ \\
Group III & $183.75^{\mathrm{c}} \pm 1.89$ & $138.50^{\mathrm{c}} \pm 1.04$ & $36.80^{\mathrm{c}} \pm 1.02$ & $93.04^{\mathrm{c}} \pm 0.93$ & $26.0^{\mathrm{c}} \pm 0.59$ \\
Group IV & $118.60^{\mathrm{a}} \pm 1.72$ & $127.40^{\mathrm{a}} \pm 1.44$ & $42.20^{\mathrm{a}} \pm 0.37$ & $69.60^{\mathrm{a}} \pm 0.79$ & $22.58^{\mathrm{a}} \pm 0.31$ \\
F (p) & $244.561^{*}$ & $273.796^{*}$ & $14.415^{*}$ & $831.619^{*}$ & $12.784^{*}$ \\
& $\left(<0.001^{*}\right)$ & $\left(<0.001^{*}\right)$ & $\left(<0.001^{*}\right)$ & $\left(<0.001^{*}\right)$ & $\left(<0.001^{*}\right)$ \\
\hline
\end{tabular}

Normally distributed data was expressed in mean \pm SE and was compared using $\mathrm{F}$ test (ANOVA) and was using Post Hoc Test (LSD) for comparison between groups. The different superscripts are significant *: Statistically significant at $\mathrm{p} \leq 0.05$, Number of animals 5 male rats/group.

Inhalation of gasoline 80 followed by concomitant treatment with vitamin $\mathrm{C}$ and vitamin E significantly ( $\mathrm{p} \leq 0.05$ ) lowers the values of TC, TGs, LDL-C and VLDL when compared with gasoline 80 inhaled group (G II). In addition, the present results showed that inhalation of gasoline 80 vapors with concomitant treatment with vitamin $\mathrm{C}$ and vitamin E significantly $(\mathrm{p} \leq 0.05)$ increased the HDL-C value when compared with gasoline 80 inhaled group.

No significant differences $(\mathrm{p} \leq 0.05)$ occurred in the levels of serum lipid profile parameters of group IV when compared with control one. Here, it was observed that administration of vitamins $\mathrm{C}$ and $\mathrm{E}$ showed ameliorative effect against gasoline 80 induced lipid profile changes.

As observed from Table 3, mean serum ALT, ALP and AST activities are significantly higher $(\mathrm{p} \leq 0.05)$ in male rats exposed to gasoline 80 vapors relative to activities obtained for rats of the control group. The activities of ALT, ALP and AST in rat exposed to gasoline 80 vapors and concomitantly treated with vitamin $\mathrm{C}$ and vitamin $\mathrm{E}$ were significantly lower $(\mathrm{p} \leq 0.05)$ compared to the activities obtained for 
male rats exposed to gasoline 80 vapors. The results of this study (Table 3) show that exposure to gasoline vapors significantly lower $(\mathrm{p} \leq 0.05)$ the concentrations of total serum protein (TSP) and albumin compared with concentration values obtained for rats in the control group. It is observed that there is a significant increase $(\mathrm{p} \leq 0.05)$ in TSP and albumin concentrations in rat exposed to gasoline vapors and concomitantly treated with vitamin $\mathrm{C}$ and vitamin E compared with group II. No significant changes $(\mathrm{p} \leq 0.05)$ in the level of TSP and albumin concentrations are observed among group IV when compared with control one.

Table 3. Serum ALT, ALP, AST, Albumin and Total protein of gasoline 80-inhaled rats administered with Vitamins $\mathrm{C}$ and $\mathrm{E}$.

\begin{tabular}{llllll}
\hline & ALT $(\mathrm{U} / \mathrm{L})$ & ALP $(\mathrm{U} / \mathrm{L})$ & AST $(\mathrm{U} / \mathrm{L})$ & $\begin{array}{l}\text { Albumin } \\
(\mathrm{mg} / \mathrm{dL})\end{array}$ & $\begin{array}{l}\text { Total protein } \\
(\mathrm{mg} / \mathrm{dL})\end{array}$ \\
\hline Group I & $32.80^{\mathrm{a}} \pm 2.50$ & $45.40^{\mathrm{a}} \pm 0.93$ & $32.60^{\mathrm{a}} \pm 0.68$ & $5.65^{\mathrm{a}} \pm 0.06$ & $8.73^{\mathrm{a}} \pm 0.09$ \\
Group II & $65.0^{\mathrm{b}} \pm 1.78$ & $126.0^{\mathrm{b}} \pm 1.91$ & $97.75^{\mathrm{b}} \pm 1.25$ & $3.49^{\mathrm{b}} \pm 0.9$ & $6.23^{\mathrm{b}} \pm 0.06$ \\
Group III & $51.50^{\mathrm{c}} \pm 2.25$ & $76.50^{\mathrm{c}} \pm 2.10$ & $64.25^{\mathrm{c}} \pm 1.80$ & $5.55^{\mathrm{a}} \pm 0.16$ & $7.58^{\mathrm{c}} \pm 0.13$ \\
Group VI & $35.80^{\mathrm{a}} \pm 2.20$ & $48.20^{\mathrm{a}} \pm 1.83$ & $33.20^{\mathrm{a}} \pm 1.28$ & $5.60^{\mathrm{a}} \pm 0.13$ & $8.30^{\mathrm{a}} \pm 0.03$ \\
F (p) & $23.110^{*}$ & $282.180^{*}$ & $262.811^{*}$ & $28.260^{*}$ & $96.648^{*}$ \\
& $\left(<0.001^{*}\right)$ & $\left(<0.001^{*}\right)$ & $\left(<0.001^{*}\right)$ & $\left(<0.001^{*}\right)$ & $\left(<0.001^{*}\right)$ \\
\hline
\end{tabular}

Normally distributed data was expressed in mean \pm SE and was compared using $F$ test (ANOVA) and was using Post Hoc Test (LSD) for comparison between groups. The different superscripts are significant *: Statistically significant at $\mathrm{p} \leq 0.05$, Number of animals 5 male rats/group.

\section{Discussion}

It was reported that some of gasoline vapors components are haematotoxic in humans (workers subjected to benzene, toluene and xylene) $[15,16]$ and the same observation was reported in experimental animals (rats exposed to gasoline vapors) [17]. In the present study, gasoline 80 inhalation significantly reduced the PCV in treated male rats. Similarly, Nigerian Qua Iboe Brent crude oil reduced the PCV in treated rats [18].

The present study showed that vapor to gasoline 80 exposure decreased the RBCs count, Hb content and PCV in treated rats. Similar results were obtained in rats treated with gasoline vapors [19], in rats treated with Nigerian Bonny light crude oil [1,2], in rats treated with cypermethrin [20] and in rats treated with Doxorubicin [21]. It was found that treating rats with crude oil was associated with anemia of the haemolytic type [18,22]. Also, gasoline 80 inhalation may cause anemia where there was a decrease in $\mathrm{Hb}$ content in treated rats. Since a number of crude oil components are lipophilic in nature, biological membranes may be the target sites where adverse effects of gasoline 80 occur. Lowering of RBC count coupled with low Hb content here may be due to destructive action of gasoline on erythrocytes and as a result of which the viability of the cells may be effected [23]. Also, it was observed that gasoline 80 inhalation caused a significant decrease in RBC count while treatment with vitamin $\mathrm{C}$ and vitamin $\mathrm{E}$ ameliorated the observed alternations in haematological 
parameters induced by gasoline 80 vapors. Ameliorative effects of vitamins (A and E) on haematotoxicity induced by gasoline vapors were reported in some studies $[19,24]$. The present study revealed that the values of TC, TGs, LDL-C, VLDL-C were increased while the value of HDL-C was decreased in serum of gasoline 80 inhaled male rats compared with control. These results are also obtained in rats exposed to gasoline fumes where there was an increase in mean of plasma TC and LDL-C levels [25], in rats exposed to gasoline vapors where exposure increased TC, TGs, LDL-C, VLDL-C and decreased HDL-C [19], in rats exposed to petrol and kerosene fumes increased TGS and TC [26], and in rabbit fed petroleum contaminated diet revealed alternation in blood lipid concentration [27]. Similar results were observed in orchiectomized rats showing modulated plasma lipid profile [28] and patients on regular hemodialysis [29]. TG and TC levels are used as indices of the liver cells damage [30,31]. The increase in lipid profile, demonstrated in this study, may be an indication that inhalation exposure to gasoline vapors may affect lipid metabolism as a result of liver damage. Oxidative strees and lipid peroxidation are among the main hypotheses of mechanism of hepatocyte injury [32]. It is well known that the oxidative stress produces reactive oxygen species (ROS) such as $\mathrm{OH}-$, $\mathrm{O}_{2}$ - hydrogen peroxide, peroxyl hydroxyl and superoxide radicals attack protein, lipid and nucleic acids which are important cell constituents provoking severe cellular alterations resulting in cell damage or death, due to their high reactivity. Peroxyl radicals are formed by lipid peroxidation, which are central species in the peroxidation chain, and cause damage of cellular membranes and key organelles such as mitochondria [33,34]. Increased lipid peroxidation and oxidative stress have been reported to be associated with exposure to gasoline vapors [35]. Oxidative stress is one of the mechanisms by which exposure to gasoline is involved in hyperglycemia and hypercholesterolemia [36]. In this study, it was also observed that inhalation of gasoline 80 with concomitant treatment with vitamin $\mathrm{C}$ and vitamin $\mathrm{E}$ produced improvement in the alteration in serum lipid concentration induced by gasoline 80 vapors in male rats. Similar results were obtained by some other workers $[27,29,37,38]$. This effect of vitamins E and C may be due to their free radical scavenging activity, as antioxidants, and ability to inhibit lipid peroxidation. It has been proved that vitamins have possible protective role against oxidative stress induced by crude oil in blood of rabbit [37].

Atherosclerosis is a cause of deaths and is characterized by low level of high HLD-C, high levels of TC (hypercholesterolaemia), LDL-C and TGs in the plasma $[39,40]$. Exposure to gasoline vapor is a crucial factor responsible for the increase in atherosclerotic risk [41]. Ability of vitamins C and E to increase HDL-C level may be beneficial in reducing the risk of atherosclerosis caused by gasoline 80 inhalation.

Liver is one of the organs affected by gasoline vapors toxicity [26]. The results of this study indicate that exposure of rats to gasoline vapor caused significant alterations in the biochemical parameters of liver function.

LAP, ALT and AST are among liver enzymes known as marker enzymes used for the assessment of the functional integrity of the liver cells [42,43] and are usually 
raised in acute hepatotoxicity or mild hepatocellular injury [42]. In this study, there was a significant increase in the activities of serum ALP, ALT and AST following the exposure to gasoline vapor. Previous workers have also noted an increase in rat liver enzymes activities after chronic exposure to gasoline vapors [44-47]. In addition, it was revealed that the activities of ALT and AST elevated in gas station workers [48]. The marker enzymes are released into the circulation after cellular damage causing rises of the levels of these enzymes [49,50]. The amounts of AST and ALT in blood are directly connected to the extent of the tissue damage. The increase in serum ALP is perhaps due to increased synthesis of ALP while increase in ALP activity suggested enhanced breakdown of phosphates to release energy in view of impaired ATPase system [51,52]. The AST and ALT are enzymes of amino acid metabolism and the increased energy demand, as a result of stress, may result in mobilization of potential energy sources including amino acid resulting in increase in ALT and AST [51]. In this work, there was also a significant decrease in the level of protein and albumin concentration compared to control. These results agree with results of other workers on female albino rats given water contaminated with 5\% engine oil [8] and on male rats exposed to gasoline vapors [2]. The function of the liver is estimated by evaluating TSP and albumin. It is well known that albumin is among plasma protein synthesized by the liver. The significant decrease in TSP and albumin in gasoline 80 vapors exposed rats indicated that gasoline exposure in this study had an effect on the synthetic function of the liver. Toxic substance inhibits the protein synthesis activity [53]. In case of lead, inhibition of protein synthesis may be due to the ability of lead to damage the endoplasmic reticulum which leads to reduction of protein synthesis [54]. Similar effect may be done by lead present in gasoline. The metabolic status of proteins indicates the physiological status of animal [55]. Also, the decrease in total proteins is due to their metabolic utilization [56]. In addition, in this study, it was observed that administration of vitamins $\mathrm{C}$ and/or $\mathrm{E}$ to rats exposed to gasoline vapors produced an appreciable improvement in the hepatotoxic effect associated with exposure. The protective effect of vitamins against hepatotoxicity was documented by some authors. The protective effect of vitamins A, E and vitamins C and E against gasoline - induced liver injury in rats was demonstrated by other workers $[5,47,57]$. Also, it has been shown that vitamins possess significant hepatoprotective activity against different hepatotoxic agents like Halothane, rifampacin, sodium nitrate and alcohol [11,58-60]. Most of the liver damages are induced by lipid peroxidation [61].

As mentioned before, the protective effect of vitamin $\mathrm{C}$ and $\mathrm{E}$, observed in this study, may be due to the action of these antioxidants against oxidative stress induced by gasoline 80 vapors. In conclusion, this study has shown that exposure to gasoline 80 vapors may cause hematological, biochemical and lipid profile changes. Vitamins $\mathrm{C}$ and $\mathrm{E}$ appeared to be promising agents for amelioration of these changes. Vitamin $\mathrm{C}$ acts in synergism with vitamin $\mathrm{E}$ where, vitamin $\mathrm{E}$ works in fats and oils which makes it complementary to vitamin $\mathrm{C}$ which works in water [11]. In the light of these results, 
vitamin $\mathrm{E}$ and vitamin $\mathrm{C}$ may play a role in the prevention of gasoline 80 vapors induced toxicity in male rats.

\section{Conclusion}

The exposure to gasoline 80 vapors causes hematological, biochemical and lipid profile changes. Vitamins $\mathrm{C}$ and $\mathrm{E}$ appeared to be promising agents for amelioration of these changes. The protective effect of vitamins $\mathrm{C}$ and $\mathrm{E}$, observed in this study, may be due to the action of these antioxidants against oxidative stress induced by gasoline 80 vapors.

\section{References}

1. A. A. Kinawy, BMC physiol. 9(1), 21 (2009). http://dx.doi.org/10.1186/1472-6793-9-21

2. F. E. Uboh, P. E. Ebong, H. D. Akpan, and I. F. Usoh, Truk. J. Biol. 36, 217 (2012).

3. G. K, Rabble and O. Wong, Environ. Health Perspect. 104, 1381 (1996).

4. C. C. Ugwoke, E. D. Nwobodo, P. Unekwe, M. Odike, S. T. Chukwuma, and G. Amilo, Nigenian J. Physiol. Sci. 20(1-2), 54 (2005).

5. F. E. Uboh, I. S. Ekaidem, P. E. Ebong, and I. B. Umoh, Gastroenterology Res. 2(3), 162 (2009).

6. F. E. Uboh, M. I. Akpanabiatu, I. J. Atangwho, P. E. Ebong, and I. B. Umoh, Acta Toxicol. 15(1), 25 (2007)

7. F. E. Uboh, M. I. Akpanabiatu, P. E. Ebong, and I. B. Umoh, Internet J. Toxicol. 5(2), 125 (2007)

8. J. I. Iheoliaha, M. V. Iwuogo, and T. E. Iihedioha, Comp. Clin. Pathol. 18, 169 (2009). http://dx.doi.org/10.1007/s00580-008-0778-3

9. S. C. Udem, I. A. M. Lekwuwa, and N. D. Udem, Comp. Clin. Pathol. 20, 19 (2009). http://dx.doi.org/10.1007/s00580-009-0945-1

10. D. R. Mattie, G. B. Marit, C. D. Flemming, and J. R. Cooper, Toxicol. Health 11(4), 423 (1995). http://dx.doi.org/10.1177/074823379501100405

11. G. Datta, S. Basu, A. S. Sen, and P. Nath, J. Pharm. Res. 5(5), 2485 (2012).

12. F. E Uboh, M. I. Akpanabiatu, M. V. Eteng, P. E. Ebong, and I. B. Umoh, Internet J. Toxicol. 26: 295 (2008b)

13. W. R. Faulkner and J. W. King, Manual of Clinical Laboratory Procedures (Chemical Rubber Company, Cleaveland Ohio, 1970) pp. 354.

14. W. T. Friedewald, R. I. Levy, and D. S. Fredrickson, Clin. Chem. 18(6), 499 (1972).

15. P. Moszczynski and J. Liseiwicz, Zentralbl Bakteriol Mikrobiol. Hug B. 178(4), 329 (1983).

16. R. Synder and C. C. Hedli, Environ. Health Prospect 104, 1165 (1996). http://dx.doi.org/10.1289/ehp.961041165

17. M. B. Abubakar, W. Z. Abduallah, S. A. Sulaiman, F. E. Uboh, and B. S. Ang, Int. J. Appl. Res. Natural Prod. 6 (4), 16 (2013).

18. U. M. Igwebuike, R. I. Obidike, S. V. O. Shoyinka, C. V. Nwankwo, I. O. Wechime, and L. O. Aka, Vet Arch. 77(3), 247 (2007).

19. F.E Uboh, M.I. Akpanabiatu, I.J. Atangwho, P.E. Ebong and I.B. Umoh, Int. J. Pharmacol. 4 (1), 40-45 (2008). http://dx.doi.org/10.3923/ijp.2008.40.45

20. M. I. Youssef, F. M. El-Demerdash, K. I. Kamel, and K. S. Al-Salhen, Toxicology 189(3), 223 (2003). http://dx.doi.org/10.1016/S0300-483X(03)00145-8 
21. M. M. Al-Harbi, N. M. Al-Gharably, O. A. Al-Shalanah, A. M. Al-Bekairi, A. M. Osman, and H. N. Tawfik, Cancer Chemother. pharmacol. 31(3), 200 (1992). http://dx.doi.org/10.1007/BF00685548

22. F. A. Leighton, B. Peakall, and R. G. Bulter, Science 220(4599), 871 (1983). http://dx.doi.org/10.1126/science.6844918

23. R. Karuppasamy, J. Environ. Poll. 7, 287 (2000).

24. F. E. Uboh, M. V. Eteng, P. E. Ebong, and I. B. Umoh, Toxicol. Indian Health 9, 559 (2010). http://dx.doi.org/10.1177/0748233710373080

25. O. L. Aberare, P. Okuonghae, N. Mukoro, J. O. Dirisu, F. Osazuwa, E. Odigie, and R. Omoregie, North Am. J. Med. Sci. 3(6), 227 (2011).

26. F. E. Uboh, M. I. Akpanabiatu, P. E. Ebong, E. V. Eyong, and O. V. Eka, Acta Biol. Szeged. 49, 19 (2005).

27. F. I. Achuba, Pak. J. Nutr. 4(5), 330 (2005). http://dx.doi.org/10.3923/pjn.2005.330.335

28. F. Deyhim, C. Gonzales, C. Garcia, A. Villarreal, K. Garcia, R. Rios, K. Mandadi, and B. S. Patil, J. Med. Food 10(3), 559 (2007). http://dx.doi.org/10.1089/jmf.2006.245

29. P. Khajehdeli, Scand. J. Urol. Nephrol. 34(1), 62 (2000).

30. A. B. Halim, O. El-Ahmady, S. Hassab-Allah, F. Abdel-Galil, Y. Hafez, and A. Darwish, Ann. Clin. Biochem. 34, 656 (1997).

31. D. V. Owu, E. E. Osim, and P. E. Ebong, Acta Tropica. 69, 65 (1998). http://dx.doi.org/10.1016/S0001-706X(97)00115-0

32. Toxicological Profile for Automotive Gasoline (Public Health Service, U.S. Department of Health and Human Services, Atlanta: GA. NTIS PB; Agency for Toxic Substances and Disease Registry, 1995); 95, p. 264206

33. G. Robertson, I. Leclercq, and G .C. Fatell, Am. J. Physiol. Gastrointest. liver Physiol. 281, 1135 (2001)

34. A. Linden, M. Guelden, H.J. Martin, E. Maser, and H. Seibert, Toxicol. In vitro 22(5), 1371-1376 (2008). http://dx.doi.org/10.1016/j.tiv.2008.02.003

35. F. E. Uboh, M. I. Akpanabiatu, I. S. Ekaidem, P. E. Ebong, and I. B. Umoh, Acta Endocrinologica 3(1), 23 (2007). http://dx.doi.org/10.4183/aeb.2007.23

36. F. Uboh, P. Ebong, and E. Udosen, Turk Jem, 14, 26 (2010)

37. F. I. Achuba and E. O. Otuya, Environmentalist. 26, 295 (2006). http://dx.doi.org/10.1007/s10669-006-0158-y

38. G. S. Gaur and A. K. Dixit, Int. J. Curr. Res. 3(11), 286 (2011).

39. D. S. Gambhir, J. K. Gambhir, and R. Subdha, Ind. Heart J. 52, 515 (2001).

40. M. T. Nasiruddin and N. Ahmad, Ind. J. Pharmacol. 38, 56 (2006). http://dx.doi.org/10.4103/0253-7613.19855

41. F. E. Uboh, M. I. Akpanabiatu, I. J. Atangwho, and Y. Alozie, J. Pharmacol. Toxicol. 3(8), 600 (2008).

42. J. J. Jens and H. Hanne, Danish hepatitis C (2002).

43. O. A. Adaramoye, D. O. Osaimoje, A. M. Akinsanya, C. M. Nneji, M. A. Fafunso, and O. G. Ademowo, Basic Clin. Pharmacol. Toxicol. 102(4), 412 (2008). http://dx.doi.org/10.1111/j.1742-7843.2008.00211.x

44. A. W. Harman, D. B. Fewin, and B. G. Priestly, Br. J. Ind. Med. 38, 91 (1981).

45. J. F. Brad, F. Xias, J. M. Gapac, S. M. Ning, and C. S. Yang, Arch. Toxicol. 64, 677 (1990). http://dx.doi.org/10.1007/BF01974697

46. C. K. Wachukwu, E. B. Dede, C. C. Ozoemena, and E. Amalas, J. Med. Lab. Sci. 13(2), 24 (2004).

47. F. E. Uboh, P. E. Ebong, H. D. Akpan, and I. F. Usoh, Truk. J. Biol. 36, 217 (2012). 
48. E. N. Karpaki, P. N. Verlas, S. V. Mairana, A. Elisabeth, E. K. Aphroditi, and P. Constantine, Arch. Environ. Health 53(4), 287 (1998).

http://dx.doi.org/10.1080/00039899809605710

49. D. S. Jacobs, Laboratory test handbook, $4^{\text {th }}$ Edition (Cleveland, OHi Lexi-comp Inc. 1996).

50. S. C. Lin, T. C. Chung, T. H. Ueng, Y. H. Linn, S. H. Hsu, and C. L. Chiang, Am. J. Clin. Med. 28, 105 (2000). http://dx.doi.org/10.1142/S0192415X00000131

51. P. S. Reddy and A. Bhagyalakshmi, Ecotoxicol Environ Saf. 29(3), 255 (1994). http://dx.doi.org/10.1016/0147-6513(94)90002-7

52. M. Kumar, M. K. Sharma, and A. Kumar, J. Health Sci. 51(4), 424 (2005). http://dx.doi.org/10.1248/jhs.51.424

53. S. Jana and N. Bandypoadhyaya, Environ. Ecol. 5(3), 488 (1987).

54. A. Sharma, V. Shama, and L. Kansal, Libyan J. Med. 5, 4621 (2010).

55. U. Satyanarayana, Biochemistry, $3^{\text {rd }}$ Edition (Arunabha Sen, Kolkata, India, 2006).

56. K. V. Swamy, R. Ravikumar, and M. P. Mohan, Bull. Environ. Contam. Toxicol. 49, 723 (1992). http://dx.doi.org/10.1007/BF00200786

57. M. I. George and O. A. Adegoke, J. Sci. Res. 3(3), 641 (2011). http://dx.doi.org/10.3329/jsr.v3i3.7671

58. A. Z. Karakilciz, A. Hayat, N. Aydiler, M. Zerin, and M. Cay, Gen. Physiol. Biophys. 24, 47 (2005).

59. V. Tayal, B. S. Kabra, S. Agarwal, N. Khurana, and M. Gupta, Ind. J. Experiment Biol. 45, 1031 (2007).

60. P. Krishnamoorthy and M. Sangeetha, Ind. J. Biochem. Biophys. 45, 206 (2008).

61. P. Muriel, Antioxidants, Oxidants and Free Radicals, (Taylor and Francis Publications, Washington, DC, 1987) pp. 237. 